\title{
DETONATION COATINGS OF COMPOSITE POWDER OF FERROMOLYBDENUM-SILICON CARBIDE PRODUCED USING METHOD OF MECHANICAL-AND-CHEMICAL SYNTHESIS
}

\author{
Yu.S. BORISOV, A.L. BORISOVA, E.A. ASTAKHOV, \\ A.N. BURLACHENKO, Z.G. IPATOVA and V.F. GORBAN \\ ${ }^{1}$ E.O. Paton Electric Welding Institute, NASU \\ 11 Bozhenko Str., 03680, Kiev, Ukraine. E-mail: office@paton.kiev.ua \\ ${ }^{2}$ I.N. Frantsevich Institute of Problems of Materials Science, NASU \\ 3 Krzhizhanovsky Str., 03680, Kiev, Ukraine. E-mail:epp@ipms.kiev.ua
}

\begin{abstract}
Investigation of formation of particles of composite powder in the process of mechanical-and-chemical synthesis at processing of mixture of powders of ferromolybdenum and silicon carbide in planetary mill was carried out. It was established that as a result of this process the formation of molybdenum carbide and also silicides of iron and molybdenum with increase of average microhardness of particles from 7270 to $10,520 \mathrm{MPa}$ is occurred. The produced powders are used for detonation spraying of coatings. The properties of coatings of powder FeMo and composite powder FeMo-SiC were investigated using methods of metallography, X-ray diffraction phase analysis, microindenting, and their resistance to wear and corrosion was measured. Basing on the results of microindenting it was established that the complex of mechanical characteristics $\left(H_{I T}, E, \varepsilon_{\mathrm{el}}, \sigma_{\mathrm{el}}\right)$ of detonation coating of composite powder FeMo-SiC exceeds as to its level the same data for the coating of powder FeMo, and values $H_{I T} / E^{*}$ and $H_{I T}^{3} / E^{* 2}$, used for evaluation of wear resistance, allow predicting increased resistance to wear for the coating $\mathrm{FeMo}-\mathrm{SiC}$ as compared to the coating FeMo. The application of map of types of structural states of material, basing on the ratio of values of $H_{I T}$ and $\varepsilon_{\mathrm{el}}$, allowed evaluating the state of coating of composite powder $\mathrm{FeMo}-\mathrm{SiC}$ as micronanostructured one. The measurements of wear and corrosion resistance of detonation coating of $\mathrm{FeMo}-\mathrm{SiC}$ as compared both to FeMo coating and also detonation coating of mixture of powders NiCrBSi-WC (according to wear resistance) and of galvanic chromium (according to corrosion resistance) showed considerable advantage of the first ones. The reasons for such increase of functional properties in detonation coating of composite powder $\mathrm{FeMo}-\mathrm{SiC}$ should be attributed to the presence of sprayed particles of products of mechanical-and-chemical synthesis, in particular of silicide phases, and high dispersity of formed structure of coatings. 14 Ref., 5 Tables, 10 Figures.
\end{abstract}

$\boldsymbol{K} \boldsymbol{e} \boldsymbol{y} \boldsymbol{w} \boldsymbol{o r} \boldsymbol{d} \boldsymbol{s}:$ detonation spraying, coating, composite powder, mechanical-and-chemical synthesis, ferromolybdenum, silicon carbide, phase composition, microhardness, microindenting, mechanical properties, micronanostrucutred state, wear resistance, electrochemical characteristics

One of the ways of modern development of thermal spraying is the development of technology of deposition of coatings with composite structure possessing increased functional properties according to the purpose of their application. Often this problem is solved using spraying of composite powders $(\mathrm{CP})$ produced using different methods, in particular, cladding, conglomeration with further sintering, and using technology of selfspreading high-temperature synthesis [1, 2].

Basing on the results of investigations of the process of interaction of transition metals $(\mathrm{Cr}$, $\mathrm{Ti})$ and non-metallic refractory compounds $(\mathrm{SiC}$,
$\mathrm{B}_{4} \mathrm{C}, \mathrm{Si}_{3} \mathrm{~N}_{4}$ ) [3-6] a number of $\mathrm{CP}$ compositions of for thermal spraying of coatings was developed, where during heating under the conditions of plasma jet the exothermal reaction of interaction with formation of carbides, borides, nitrides and silicide matrix (in case $\mathrm{SiC}$ and $\mathrm{Si}_{3} \mathrm{~N}_{4}$ ) is proceeding. The produced coatings demonstrated high resistance to wear [4].

The further step in the development of this trend of creation of $\mathrm{CP}$, designed for deposition of coatings with high functional properties, is the application as metallic component at ineraction with non-metallic refractory compound of different ferroalloys (FeTi, FeV) [7-9]. To form $\mathrm{CP}$ the conglomeration of mechanic mixture of powders with the following sintering was used. The results of investigation of wear resistance of coatings produced of these powders using meth- 


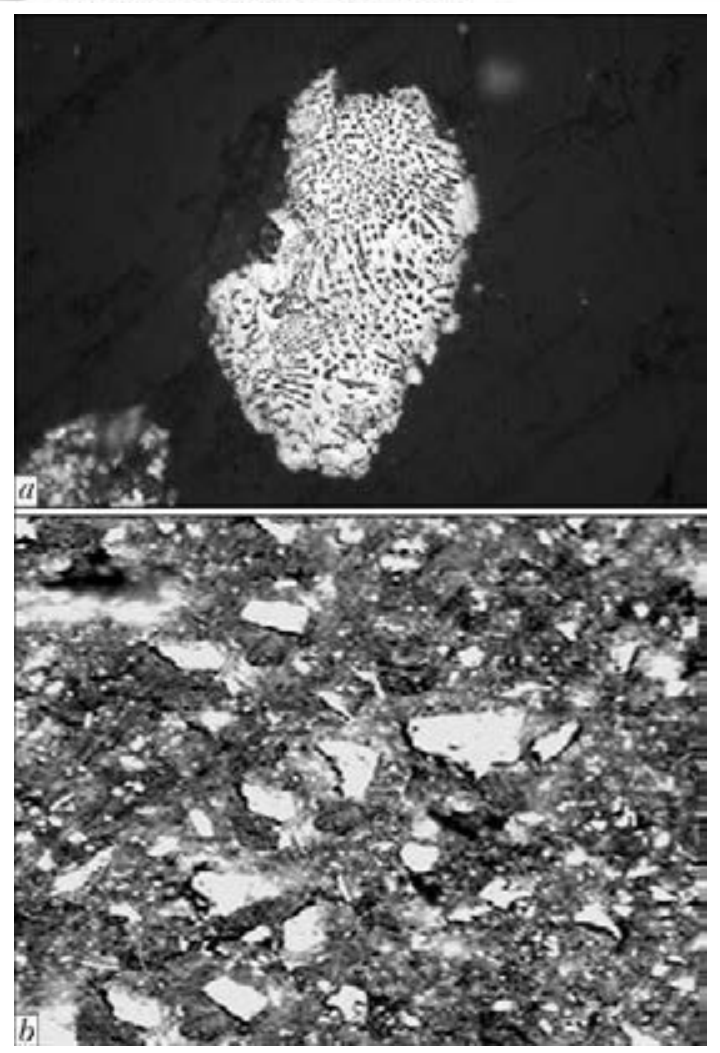

Figure 1. Microstructure $(\times 500)$ of particles of initial powders: $a-\mathrm{FeMo} ; b-\mathrm{SiC}$

ods of plasma and detonation spraying proved the efficiency of development of this trend [9].

In the present work the results of investigation of process of formation of CP particles of mixture of ferroalloy FeMo and $\mathrm{SiC}$ using method of mechanical-and-chemical synthesis (MCS) [10], having wide challenges in the field of development of saving and efficient technology of $\mathrm{CP}$ production, and also study of structure and properties of detonation coatings of $\mathrm{FeMo}^{-} \mathrm{SiC} \mathrm{CP}$ are given.

Methods of experiment. As the initial materials for producing of $\mathrm{FeMo}-\mathrm{SiC} \mathrm{CP}$ the alloy of ferromolybdenum (GOST 4759-91), which was crushed to the size of particles of not more than $100 \mu \mathrm{m}$, and silicon carbide (GOST 3647-71)
Table 1. Thermodynamic activity of process of synthesis of products of the most probable reactions in $\mathrm{FeMo}-\mathrm{SiC}$ system

\begin{tabular}{||c|c|c|c||}
\hline Reaction & $\begin{array}{c}\mathrm{SiC}, \\
\mathrm{wt} . \%\end{array}$ & $\begin{array}{c}\Delta H_{298}^{0}, \\
\mathrm{~kJ} / \mathrm{mole}\end{array}$ & $\begin{array}{c}\Delta T_{\text {ad }}, \\
\mathrm{K}\end{array}$ \\
\hline $5 \mathrm{Mo}+\mathrm{SiC}=\mathrm{Mo}_{2} \mathrm{C}+\mathrm{Mo}_{3} \mathrm{Si}$ & 7.7 & -85.02 & 342 \\
\hline $3 \mathrm{Fe}+\mathrm{SiC}=\mathrm{Fe}_{3} \mathrm{Si}+\mathrm{C}$ & 19.0 & -27.98 & 167 \\
\hline
\end{tabular}

with the size of particles of not more than $3 \mu \mathrm{m}$, were used.

The composition of initial mixture was selected basing on the thermodynamic evaluation of possible reactions of silicon carbide with molybdenum and iron. The calculations showed that in interaction of $\mathrm{SiC}$ with iron the reaction of formation of iron silicide $\left(\mathrm{Fe}_{3} \mathrm{Si}\right)$ is most probable from the thermodynamic aspect with precipitation of free carbon, while in interaction of $\mathrm{SiC}$ with molybdenum the reaction of formation of mixture of molybdenum carbide $\left(\mathrm{Mo}_{2} \mathrm{C}\right)$ with molybdenum silicide $\left(\mathrm{Mo}_{3} \mathrm{Si}\right)$ is probable. These reactions are characterized by maximum values of heat effect and adiabatic increase of temperature (Table 1).

As the ferromolybdenum contained 65 wt.\% Mo and 35 wt.\% Fe, then according to the calculation it is necessary to add 11.65 wt.\% $\mathrm{SiC}$ to the mixture for full running of above-mentioned reactions.

The process of MCS of mixture of powders of the mentioned composition was performed using planetary mill «Aktivator-2S» in the air environment at the speeds of drum rotation of $1500 \mathrm{rpm}$, ratio of mass of balls to the mass of charge was $10: 1$ during the period of $0.5-5.0 \mathrm{~h}$. In the MCS process after $0.5,1.5,3$ and $5 \mathrm{~h}$ of treatment the samples were taken for investigation of phase composition of mixture, hardness, size and shape of particles.

Detonation coatings were sprayed on steel specimens in the installation «Perun-S» at the consumptions, $\mathrm{m}^{3} / \mathrm{h}$ : propane-butane -0.5 ,
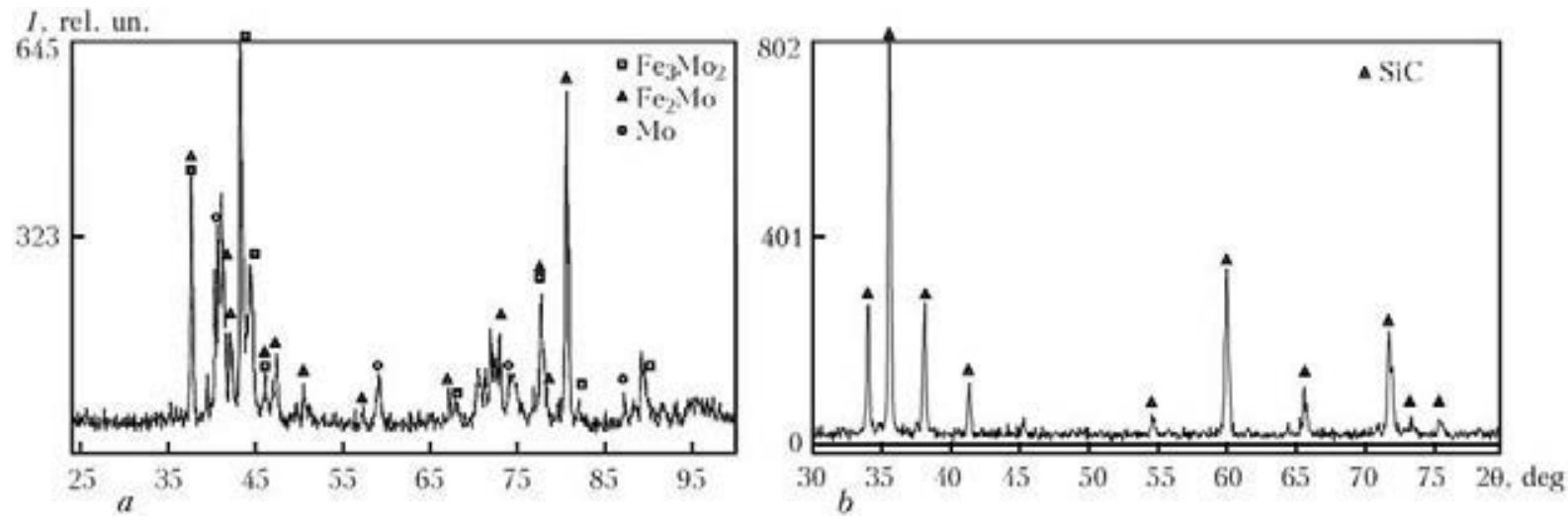

Figure 2. X-ray photographs of initial powders: $a-\mathrm{FeMo} ; b-\mathrm{SiC}$ 
oxygen -1.3 , air -0.65 , air for transportation of powder -0.12 , and spraying distance of $100 \mathrm{~mm}$.

$\mathrm{CP}$ and sprayed coatings were investigated using methods of metallographic analysis, X-ray diffraction phase analysis (X-ray DPA) (installation DRON-UM-1, radiation $\mathrm{Cu}_{\alpha}$, monochromatized), microdurometric analysis (at indenter load of $25 \mathrm{~g}$ for powders and $50 \mathrm{~g}$ for coatings) and also microindenting (of coatings only).

Microindenting was carried out in the installation «Micron-gamma» at room temperature (loading in the range of up to $F=2 \mathrm{~N}$ ) using Berkovich diamond pyramid at the sharpening angle of $65^{\circ}$ at automatically performed loads and unloads during $30 \mathrm{~s}$. Simultaneously, the record of diagram of loading, holding and unload in the coordinates $F-h$ was carried out. Accuracy of determination of force $F$ amounted to $10^{-3} \mathrm{~N}$, depth of penetration of indenter $h$ was $\pm 2.5 \mathrm{~nm}$. Values of diagram $F, h_{\max }, h_{\text {res }}, h_{\mathrm{c}}$ were fixed according to the data of 2,000 points on the diagram of indenting [11]. Calculation of such characteristics of material as hardness $H_{I T}$, contact modulus of elasticity $E^{*}$ was carried out according to the standard ISO 14577-1:2002(E).

Wear under the conditions of dry friction of sliding was investigated in the friction machine $\mathrm{M}-22 \mathrm{M}$, where it was possible to measure simultaneously the coefficient of friction, wear of
Mo, wt.\%

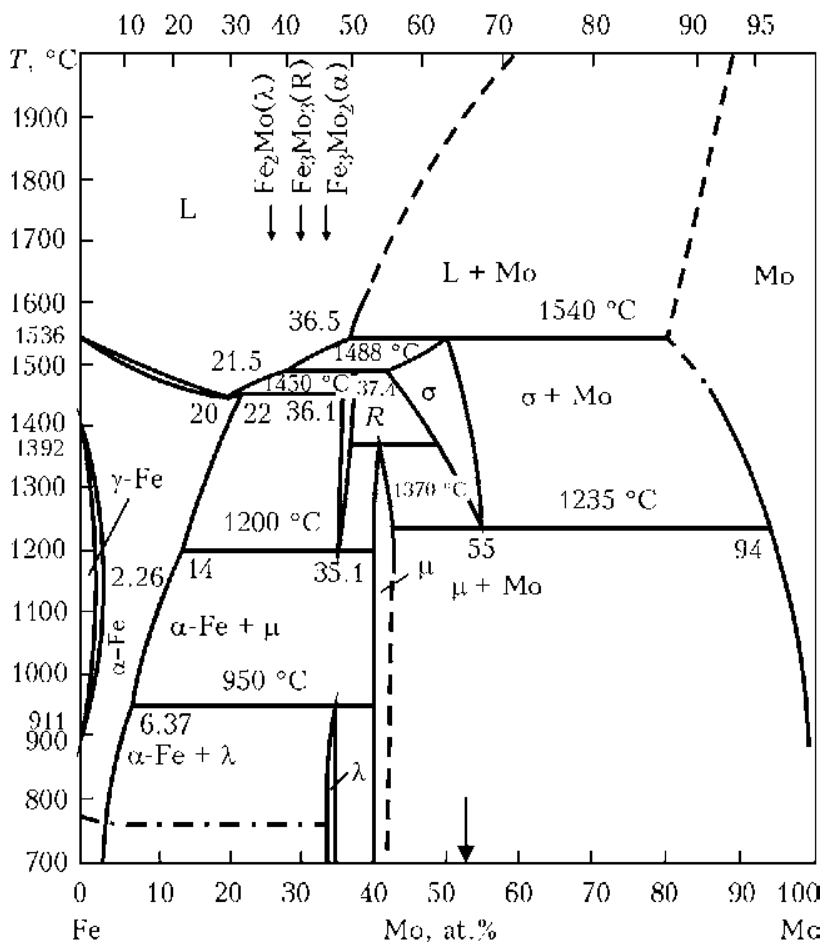

Figure 3. Constitutional diagram of FeMo systems (arrow indicates the composition of alloy)

specimen with coating and temperature in the contact zone. The coating was deposited on the insert of steel 45, the shaft of hardened steel 45 (HRC 55-58) served as a mating body. The tests were carried out at the loading of $2 \mathrm{MPa}$ and
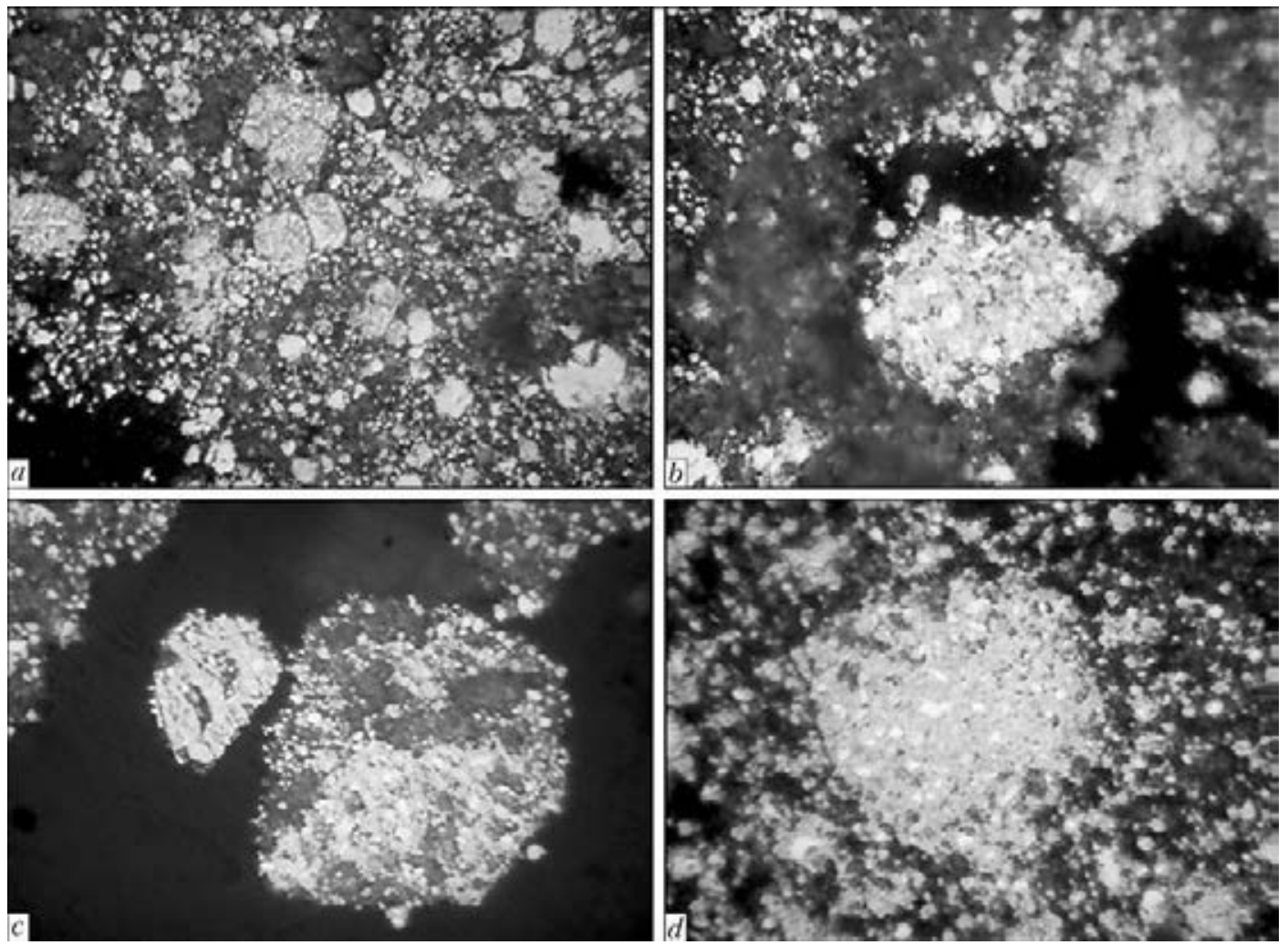

Figure 4. Microstructure $(\times 1000)$ of powder particles of FeMo-SiC system produced using MCS method at different duration of treatment: $a-0.5 ; b-1.5 ; c-3 ; d-5 \mathrm{~h}$; etched 


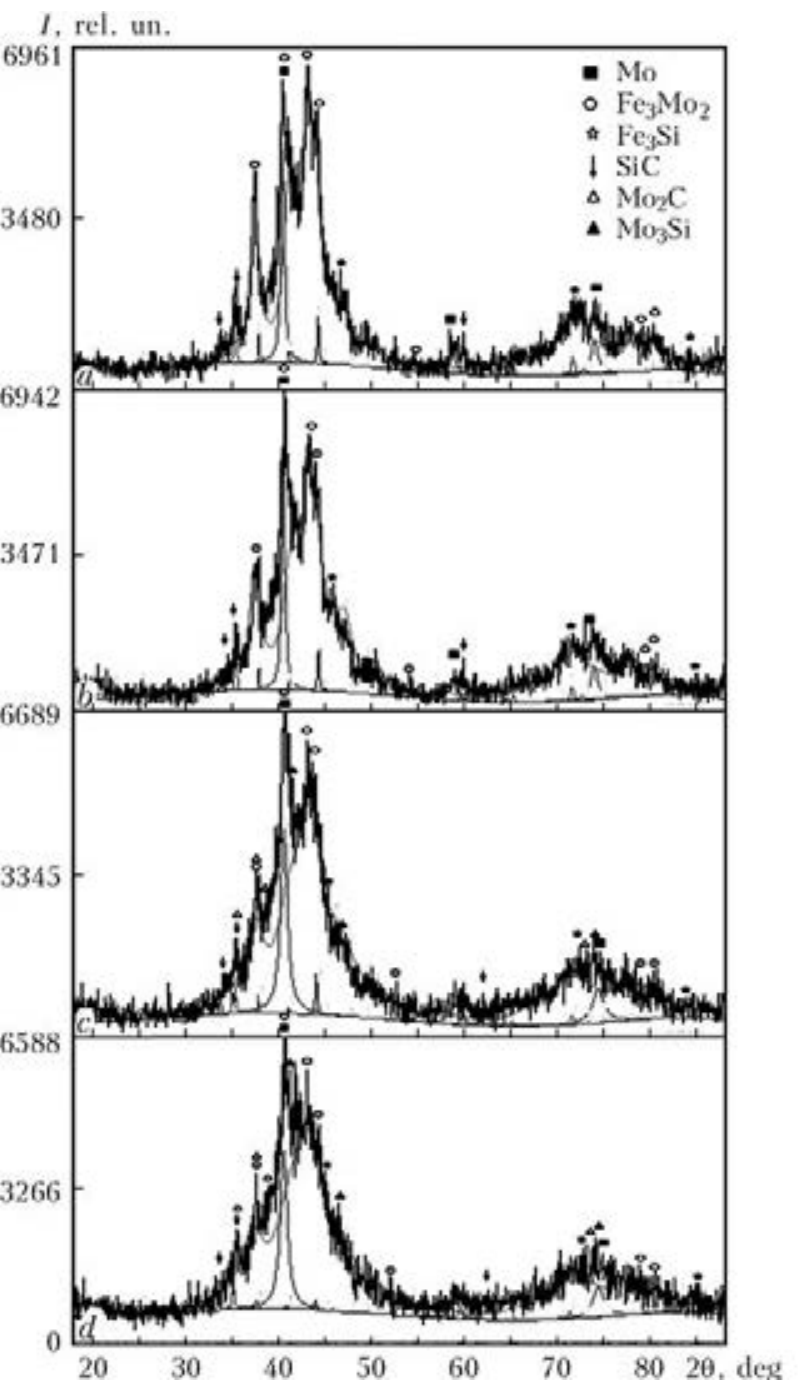

Figure 5. X-ray photographs of powder particles of FeMoSiC system depending on duration of MCS: $a-0.5 ; b-$ $1.5 ; c-3 ; d-5 \mathrm{~h}$

speed of sliding of $5 \mathrm{~m} / \mathrm{s}$. The path of sliding was 4 and $5 \mathrm{~km}$.

Corrosion resistance of coatings in sea water and $10 \%$ solution of $\mathrm{H}_{2} \mathrm{SO}_{4}$ was investigated using method of measurement of polarization potential in the potential controlling device P5827M using three-electrode cell YaSE-2.

Experiment results. During investigation of structure and phase composition of initial powders (Figures 1 and 2) it was established that ferromolybdenum, containing 65 wt.\% Mo according to GOST 4759-91, consists of molybdenum $\mathrm{Fe}_{3} \mathrm{Mo}_{2}$ ( $\mu$-phase), and silicon carbide only of $\alpha-\mathrm{SiC}$, as is followed from the equilibrium constitutional diagram (Figure 3).

In the process of MCS of powder mixture FeMo +11.65 wt. $\% \mathrm{SiC}$ at the initial stage $(0.5 \mathrm{~h})$ the refining of metallic particles FeMo with embedding of fine-dispersed particles of initial silicon carbide to them is observed (Figure 4, a). Further on, the formation of composite particles composed of initial components (Figure 4, $b$ ) and also products of their chemical interaction (Figure $4, c, d$ ) is occurred. On the X-ray photographs of samples of powders taken from the reactor in the process of MCS, due to a high level of their cold working, on the background of halo, which evidences of high level of amorphisation of particles, one can detect only single $\mathrm{X}$-ray lines of initial phases $\left(\mathrm{Fe}_{3} \mathrm{Mo}_{2}, \mathrm{SiC}\right)$ and products of their interaction $\left(\mathrm{Mo}_{2} \mathrm{C}, \mathrm{Mo}_{3} \mathrm{Si}\right.$ and $\mathrm{Fe}_{3} \mathrm{Si}$ ) ( $\mathrm{Fi}$ gure 5), formation of which was supposed according (see Table 1) to the thermodynamic evaluation of possible reactions of molybdenum and iron with $\mathrm{SiC}$.

Microhardness of particles of $\mathrm{FeMo}-\mathrm{SiC} \mathrm{CP}$ with increase of duration of MCS grows monotonously reaching 10,520-1720 $\mathrm{MPa}$ at the period of treatment of mixture of $5 \mathrm{~h}$ (Table 2). At variation curves of microhardness two maximums are observed, which signify two the most obvious and characteristic values of hardness of particles (Figure 6). It is characteristic that with increase of duration of MCS both maximums and also the average value of microhardness of particles move to the region of the higher values.

For detonation spraying of coatings the FeMo-SiC CP, produced by MCS at the time of processing of $5 \mathrm{~h}$, and the powder of ferromolybdenum with the size of particles of not more than $63 \mu \mathrm{m}$, were used for comparison. In both cases the dense, thin lamellar coatings with oxide sublayers at the boundaries of lamellas and small number of round metallic particles are formed. Defects and delaminations of coatings at the

Table 2. Phase composition and microhardness of $\mathrm{CP}$ of $\mathrm{FeMo}-\mathrm{SiC}$ system depending on MCS duration

\begin{tabular}{|c|l|c|c||}
\hline \hline \multirow{2}{*}{$\begin{array}{c}\text { Duration of } \\
\text { MCS, } \mathrm{h}\end{array}$} & \multicolumn{1}{|c|}{ Phase composition } & \multicolumn{2}{|c||}{ Microhardness, MPa } \\
\cline { 2 - 4 } & \multicolumn{1}{|c|}{ Average } & Most probable \\
\hline Initial & $\mathrm{Fe}_{3} \mathrm{Mo}_{2}, \mathrm{Mo}, \mathrm{SiC}$ & $7270 \pm 1870(\mathrm{FeMo}), 27200(\mathrm{SiC})[12]$ & - \\
\hline 0.5 & $\mathrm{Fe}_{3} \mathrm{Mo}_{2}, \mathrm{Mo}, \mathrm{SiC}$, amorphous phase & $7950 \pm 1760$ & 6375,11125 \\
\hline 1.5 & $\mathrm{Fe}_{3} \mathrm{Mo}_{2}, \mathrm{Mo}, \mathrm{SiC}$, amorphous phase & $8710 \pm 2230$ & 7750,11250 \\
\hline 3.0 & $\mathrm{Fe}_{3} \mathrm{Mo}_{2}, \mathrm{Mo}, \mathrm{Mo}_{2} \mathrm{C}, \mathrm{Mo}_{3} \mathrm{Si}, \mathrm{Fe}{ }_{3} \mathrm{Si}, \mathrm{SiC}$, amorphous phase & $10090 \pm 1530$ & 8900,11300 \\
\hline 5.0 & $\mathrm{Fe}_{3} \mathrm{Mo}_{2}, \mathrm{Mo}, \mathrm{Mo}_{2} \mathrm{C}, \mathrm{Mo}_{3} \mathrm{Si}, \mathrm{Fe}{ }_{3} \mathrm{Si}, \mathrm{SiC}$, amorphous phase & $10520 \pm 1720$ & 9700,11750 \\
\hline
\end{tabular}



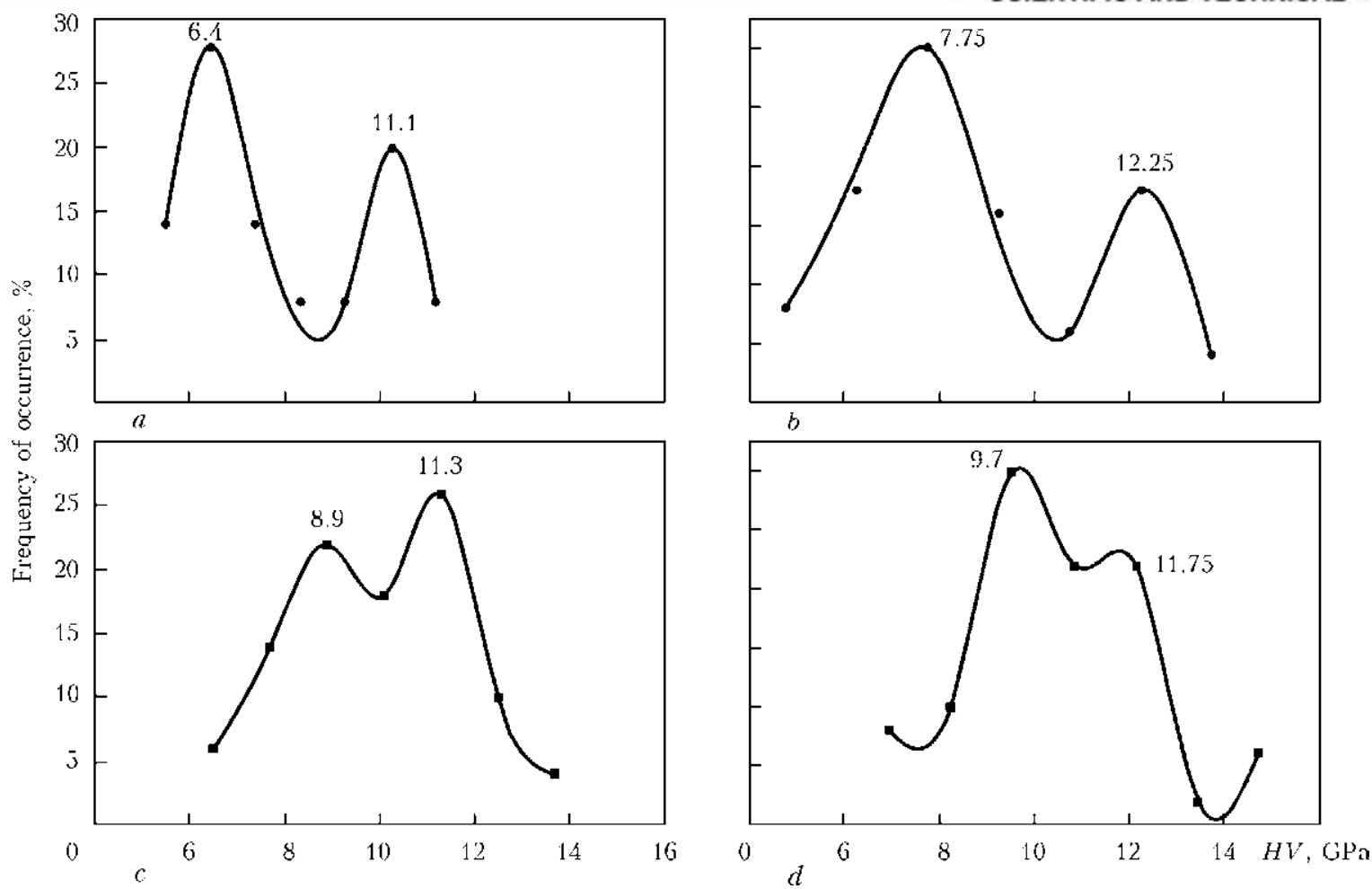

Figure 6. Variation curves of microhardness of $\mathrm{CP}$ particles of $\mathrm{FeMo}-\mathrm{SiC}$ system depending on the duration of MCS: $a-0.5 ; b-1.5 ; c-3 ; d-5 \mathrm{~h}$

boundary with the base were not observed ( $\mathrm{Fi}$ gure 7).

According to the results of X-ray DPA, the complex oxide $\mathrm{Fe}_{2} \mathrm{MoO}_{4}$ was revealed in the coating of ferromolybdenum except the basic phase of initial powder, while in the coating of $\mathrm{FeMo}^{-}$ $\mathrm{SiC} \mathrm{CP}$, except the phases included into the composition of initial powder, the same oxide $\mathrm{Fe}_{2} \mathrm{MoO}_{4}$ and disilicide of molybdenum $\mathrm{MoSi}_{2}$ were revealed (Figure 8). It can evidence about active proceeding of interfacial interaction of $\mathrm{CP}$ components under the conditions of detonation spraying, all the more the traces of $\mathrm{SiC}$ in the coating were not detected.

The mechanical characteristics of coatings of powders of ferroalloy FeMo (with content of 65 wt.\% Mo) and products of MCS in the mixture $\mathrm{FeMo}-\mathrm{SiC}$ were investigated using method of microindenting (Figure 9).

According to the modern existing point of view in evaluating the surface of resistance to wear it is necessary to consider not only the value of its hardness, but also to the same extent the modulus of elasticity of its material. Therefore, at the present time the ratio $H / E$ is used as the characteristic of wear resistance of surface [13].

At the same time, the behavior of coatings in the process of wear depends on the level of its resistance to plastic deformation, which is proportional to the value of ratio $H^{3} / E^{2}$ [13]. Therefore, the above-mentioned characteristics of me- chanical properties of materials and coatings, determined as a result of application of method of
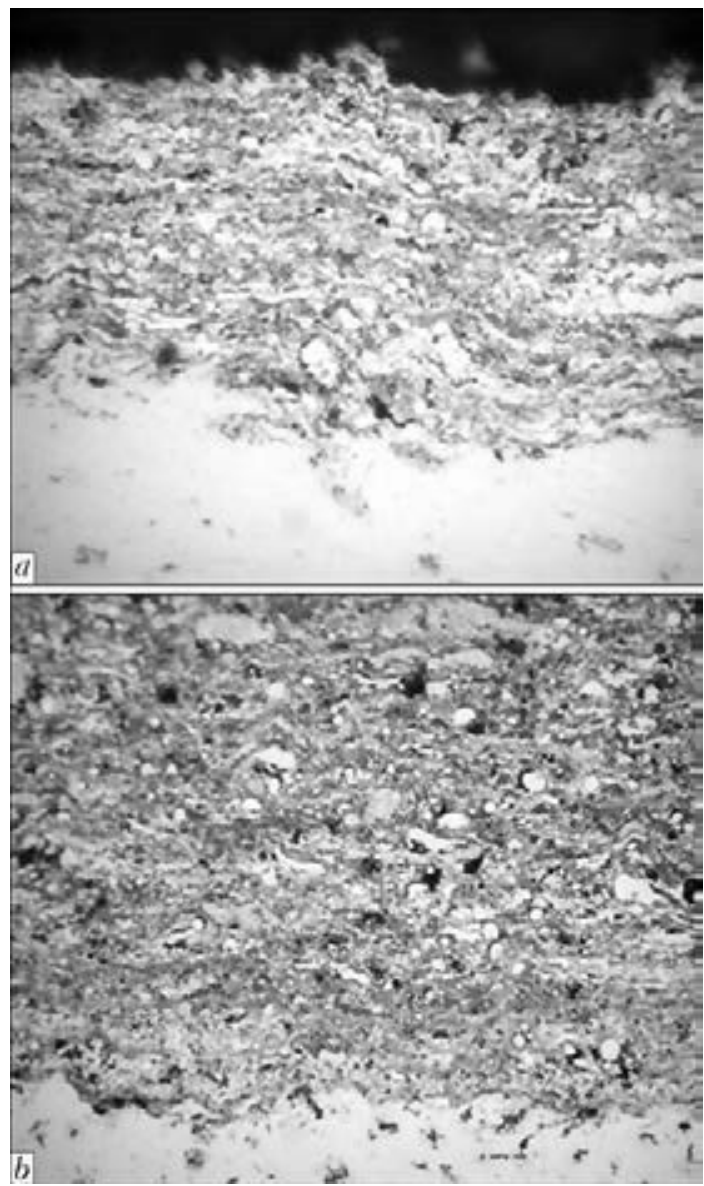

Figure 7. Microstructure $(\times 400)$ of detonation coatings of ferromolybdenum $(a)$ and $\mathrm{FeMo}^{-} \mathrm{SiC} \mathrm{CP}(b)$ 

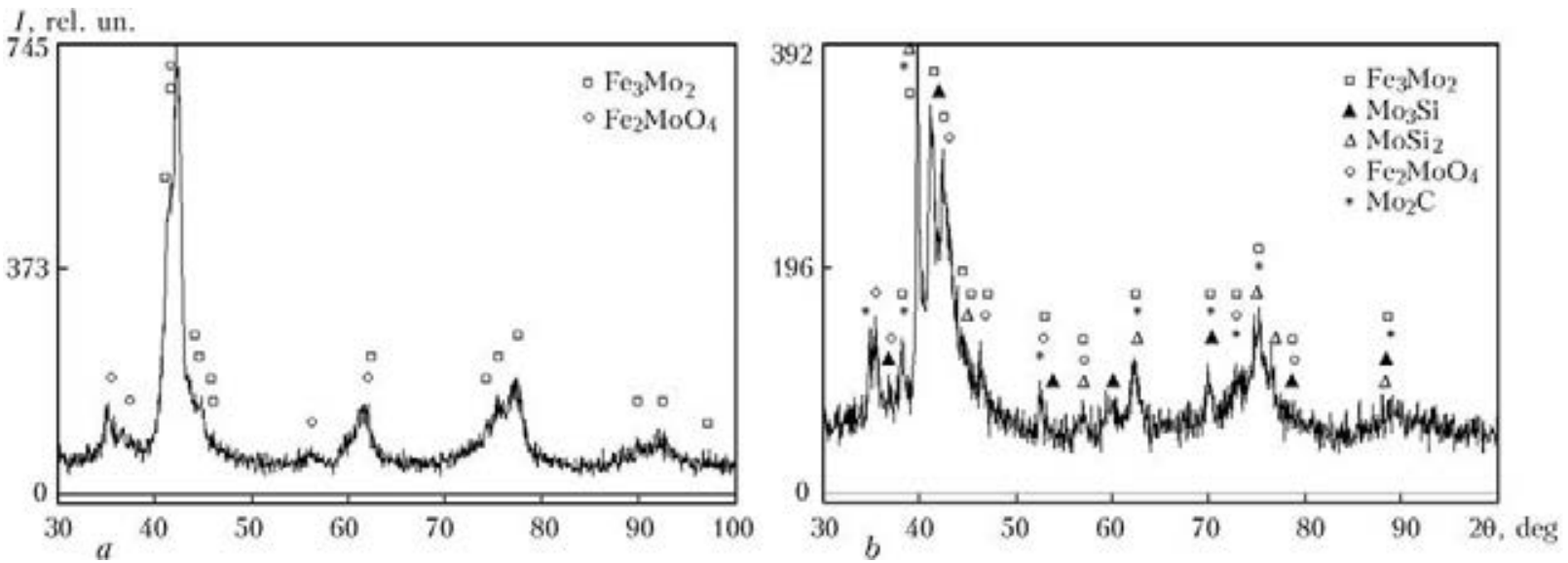

Figure 8. X-ray photographs of detonation coatings of powder FeMo $(a)$ and $\mathrm{FeMo}-\mathrm{SiC} \mathrm{CP}(b)$
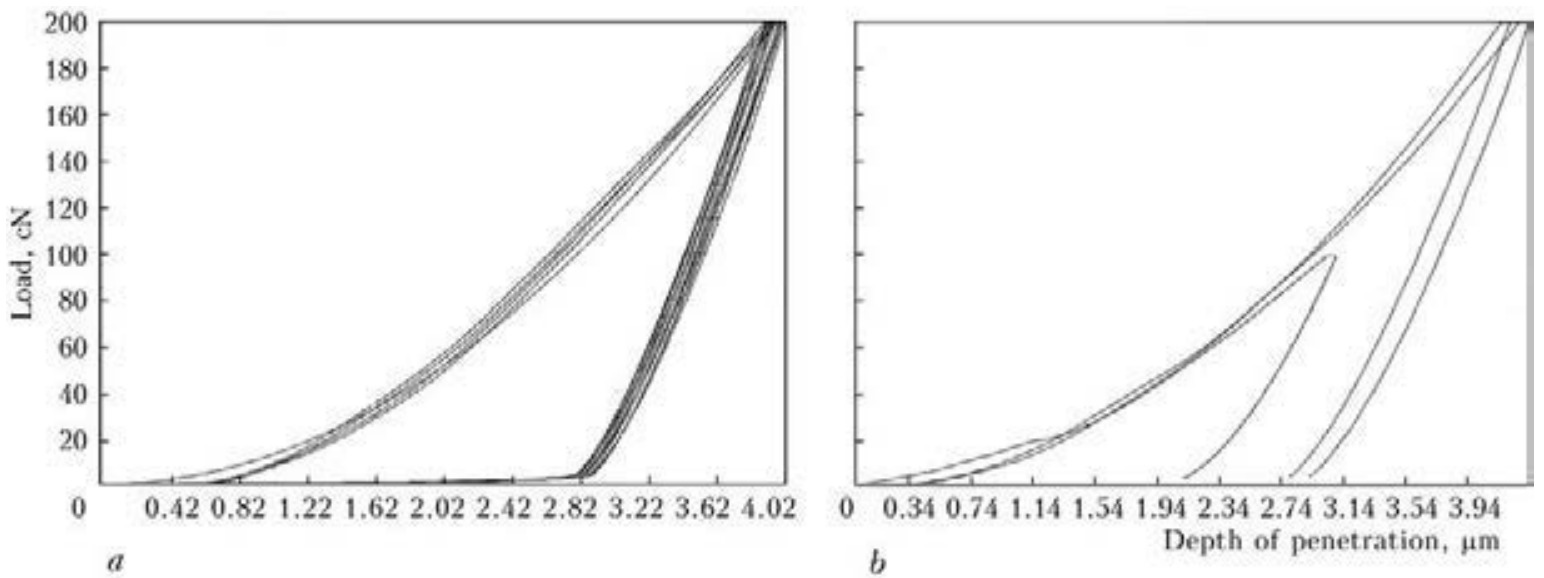

Figure 9. Diagram of detonation coatings of powder of ferroalloy FeMo $(a)$ and FeMo-SiC CP (b) obtained using microindenting

nano- (or micro-) indenting, are used as the criteria of their wear resistance [13, 14]. As the generalization of results of measurements of these characteristics for a wide range of materials and coatings showed, their value depends both on the composition as well as on the structural state of material of surface (single- and coarse-crystalline, fine and nanocrystalline, amorphous and amorphous-nanocrystalline) [11].

Coming from the above-mentioned, for evaluation of wear resistance of coatings $\mathrm{FeMo}^{-} \mathrm{SiC}$ the parameters $H_{I T} / E^{*}$ and $H_{I T}^{3} / E^{* 2}$ were added to the obtained data of microindenting, presented in Table 3.

The analysis of results of microindenting shows that coating, produced of $\mathrm{CP}$ of the system $\mathrm{FeMo}-\mathrm{SiC}$, has higher values of wear resistance than the coating produced of the powder FeMo. Thus, parameters $H / E^{*}$ grow from 0.066 to 0.080

Table 3. Results of microindenting of detonation coatings of $\mathrm{FeMo}-\mathrm{SiC}$ system

\begin{tabular}{|c|c|c|}
\hline \multirow[b]{2}{*}{ Characteristic of microindenting } & \multicolumn{2}{|c|}{ Composition of sprayed powders } \\
\hline & $\begin{array}{l}\text { Ferroalloy FeMo } \\
\text { (65 wt.\% Mo) }\end{array}$ & $\begin{array}{l}\text { Product of MCS FeMo } \\
(65 \text { wt. } \% \mathrm{Mo})+\mathrm{SiC}\end{array}$ \\
\hline Maximum depth of penetration of indenter $h_{\max }, \mu \mathrm{m}$ & 3.934 & 3.575 \\
\hline Contact depth of penetration of indenter $h_{c}, \mu \mathrm{m}$ & 3.256 & 2.856 \\
\hline Hardness at indenting of $H_{I T}, \mathrm{GPa}$, in the dent contact region of depth $h_{\mathrm{c}}$ & $7.7 \pm 3$ & $10.3 \pm 25$ \\
\hline Contact modulus of elasticity $E^{*}, \mathrm{GPa}$ & 115.0 & 127.6 \\
\hline$H_{I T} / E^{*}$ & 0.066 & 0.080 \\
\hline$H_{I T}^{3} / E^{* 2}$ & 0.0345 & 0.0670 \\
\hline Relative out-of-contact elastic strain $\varepsilon_{\mathrm{el}}, \%$ & 2.04 & 2.47 \\
\hline Stress of out-of-contact elastic strain $\varepsilon_{\mathrm{el}}, \mathrm{GPa}$ & 2.5 & 3.16 \\
\hline
\end{tabular}


and $H_{I T}^{3} / E^{* 2}-$ from 0.0345 to 0.0670 . Growth of parameters $\varepsilon_{\mathrm{el}}$ and $\sigma_{\mathrm{el}}$ (from 2.04 to 2.47 and from 2.50 to 3.16 , respectively) evidence also of improvement of ductile properties of $\mathrm{CP}$ coating of the system $\mathrm{FeMo}-\mathrm{SiC}$, as compared to the coating of pure ferroalloy FeMo, in particular increase of its resistance to abrasive wear. Besides, the combination of simultaneous growth of $H_{I T}$ and $\varepsilon_{\mathrm{el}}$ at consideration of map of types of structural states of materials, suggested by the authors of work [11], can evidence of shifting the structure of coating from $\mathrm{CP}$ of the system $\mathrm{FeMo}-\mathrm{SiC}$ (as compared to the FeMo coating) to the region of nanocomposite one containing micro- and nanodimensional phases (Figure 10). This is confirmed also by X-ray photographs of coatings (see Figure 8), where larger widening of peaks in case of coating of $\mathrm{FeMo}^{-} \mathrm{SiC} \mathrm{CP}$ is observed.

To evaluate the functional properties of produced $\mathrm{FeMo}-\mathrm{SiC}$-coating the measurement of its tribotechnical and electrochemical characteristics was carried out. In Table 4 the results of determination of linear wear and coefficient of friction of investigated detonation coatings under the conditions of dry friction on the path of $4 \mathrm{~km}$ at loading of $2 \mathrm{MPa}$, as compared to detonation coating of mechanical mixture $\mathrm{NiCrBSi}$ PG-10N-01 + WC $(63 / 35)$ alloy and steel 45 with $H R C 55-58$, are given. As we see, in detonation coating of $\mathrm{FeMo}-\mathrm{SiC} \mathrm{CP}$ the resistance to wear under the conditions of dry friction is 5-10 times higher than for FeMo alloy coating, 2.5-5 times higher than for coating of powder containing 65 wt.\% of nickel self-fluxing alloy PG-10N-01 in mixture with 35 wt.\% WC, and 35-75 times higher than that of steel 45. The coefficient of friction in this case is maintained

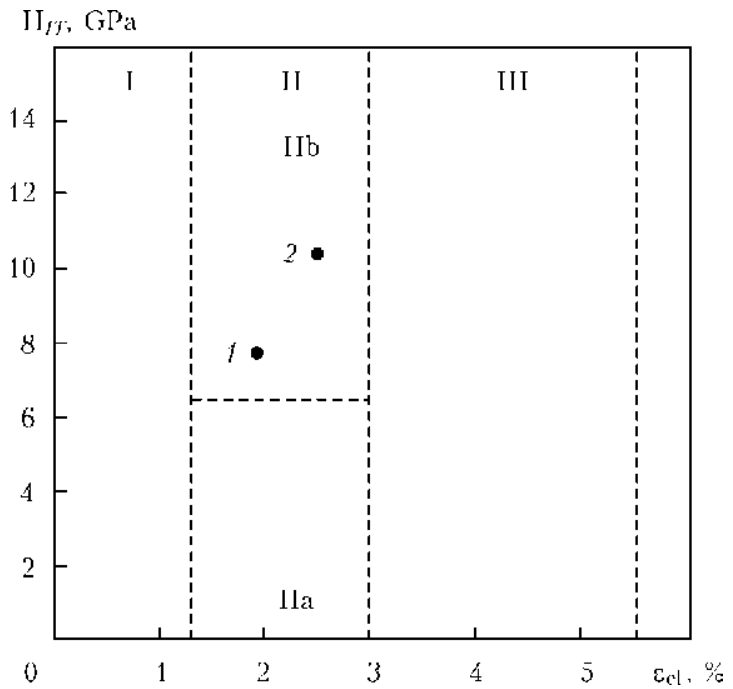

Figure 10. Map of types of structural state of materials [11]: I - coarse-crystalline; IIa - fine-crystalline; IIb nanocrystalline; III - amorphous-nanocrystalline; 1 FeMo; 2 - FeMo-SiC CP coating

at the level of $0.6-0.7$. These results coincide with high wear resistance of coating of $\mathrm{FeMo}-\mathrm{SiC} \mathrm{CP}$ predicted above based on the values $H_{I T} / E^{*}$ and $H_{I T}^{3} / E^{* 2}$, and obviously connected both with its structural state and also with phase composition.

The results of measurement of electrochemical characteristics of coatings, given in Table 5, evidence of high corrosion resistance of detonation coating of $\mathrm{FeMo}-\mathrm{SiC} \mathrm{CP}$ not only as compared to FeMo-coating but also to galvanic chromium coating.

The estimated rate of corrosion of detonation coating of $\mathrm{FeMo}-\mathrm{SiC} \mathrm{CP}$ in sea water amounts to 0.077 against 0.1 and $0.18 \mathrm{~mm} /$ year for FeMo coating and galvanic chromium one. According to this fact the service life of protective coating $0.5 \mathrm{~mm}$ thick is equal to $6.7,4.8$ and 4.5 years for coatings of $\mathrm{FeMo}-\mathrm{SiC} \mathrm{CP}, \mathrm{FeMo}$ and galvanic chromium, respectively. The reasons of

Table 4. Linear wear and coefficient of friction of detonation coatings

\begin{tabular}{||c|c|c|c||}
\hline \hline Material of coating & Method of preparation of powder & Linear wear, $\mu \mathrm{m} / \mathrm{km}$ & Friction coefficient \\
\hline FeMo & Refined alloy & 20 & 0.6 \\
\hline FeMo-11.65SiC CP & MCS & $2-4$ & $0.6-0.7$ \\
\hline PG-10H-01+WC & Mechanical mixture $(65 / 35)$ & 11 & 0.6 \\
\hline Steel 45 & - & 145 & 0.72 \\
\hline
\end{tabular}

Table 5. Electrochemical characteristics of detonation coatings in different testing environment

\begin{tabular}{||l|c|c|c|c||}
\hline \multirow{2}{*}{\multicolumn{1}{c|}{ Material of coating }} & \multicolumn{2}{|c|}{$10 \% \mathrm{H}_{2} \mathrm{SO}_{4}$ water solution } & \multicolumn{2}{c||}{ Sea water } \\
\cline { 2 - 5 } & Corrosion potential $E, \mathrm{~V}$ & $\begin{array}{c}\text { Rate of corrosion } i \cdot 10^{5}, \\
\mathrm{~A} / \mathrm{cm}^{2}\end{array}$ & $\begin{array}{c}\text { Corrosion potential } E, \mathrm{~V} \\
\text { Rate of corrosion } i \cdot 10^{6}, \\
\mathrm{~A} / \mathrm{cm}^{2}\end{array}$ \\
\hline FeMo & -0.20 & 6.4 & -0.32 & 9.2 \\
\hline FeMo-11.65SiC CP (MCS) & -0.12 & 3.6 & -0.32 & 5.0 \\
\hline Galvanic chromium & -0.12 & 720 & -0.18 & 9.6 \\
\hline
\end{tabular}


such increase of corrosion resistance should be attributed to appearance of silicide phases in the coating, and also, probably, to the peculiarities of structural state of detonation coating of FeMo-SiC CP.

\section{Conclusions}

1. As a result of MCS process proceeding during $5 \mathrm{~h}$ in the planetary mill, the $\mathrm{CP}$ particles are formed of mixture of powders of ferroalloy FeMo and $\mathrm{SiC}$ containing, except of $\mathrm{Fe}_{3} \mathrm{Mo}_{2}$ and $\mathrm{Mo}$, the products of synthesis in the form of $\mathrm{Mo}_{2} \mathrm{C}$, $\mathrm{Mo}_{3} \mathrm{Si}$ and $\mathrm{Fe}_{3} \mathrm{Si}$. Here, the average microhardness of particles on the base of FeMo is increased from 7270 to $10,520 \mathrm{MPa}$.

2. Using powders $\mathrm{FeMo}-\mathrm{SiC}$ with size of particles of less than $63 \mu \mathrm{m}$ for detonation spraying the dense coatings were produced containing phases $\mathrm{MoSi}_{2}$ and $\mathrm{Fe}_{2} \mathrm{MoO}_{4}$ with features of amorphisation of coating, except of phase components of initial powder.

3. Using method of microindenting the measurement of mechanical characteristics of coatings of $\mathrm{FeMo}$ and $\mathrm{FeMo}-\mathrm{SiC} \mathrm{CP}$ was carried out. It was found that coating of products of MCS of FeMo-SiC possesses a complex of properties described by the criteria $H_{I T} / E^{*}$ and $H_{I T}^{3} / E^{* 2}$, the values of which allow predicting its increased wear resistance as compared to FeMo coating (respectively, for the coatings of FeMo and FeMo$\mathrm{SiC} \mathrm{CP} H_{I T} / E^{*}$ is equal to 0.066 and 0.080 , $H_{I T}^{3} / E^{* 2}$ is 0.0345 and 0.0670 ).

4. The analysis of nature of structure of coatings using the map of types of structural states showed that in case of application of $\mathrm{FeMo}-\mathrm{SiC}$ CP produced by MCS for detonation spraying, the coating according to its mechanical characteristics lies in the region of micronanostructured state.

5. During investigation of tribotechnical and electrochemical characteristics of detonation coatings of powders FeMo and $\mathrm{FeMo}-\mathrm{SiC} \mathrm{CP}$ it was established that coatings, produced of MCS products $\mathrm{FeMo}-\mathrm{SiC}$, have higher wear (under the conditions of dry friction) and corrosion resistance (in $10 \% \mathrm{H}_{2} \mathrm{SO}_{4}$ solution and sea water) than FeMo coating, and also coating of mixture PG-10N-01 with WC (in case of wear) and of galvanic chromium (under the conditions of corrosion effect). The reasons for this fact are the formation of silicide phases in the coatings and also increased dispersity of their structure.

1. Kulik, A.Ya., Borisov, Yu.S., Mnukhin, A.S. et al. (1985) Thermal spraying of composite powders. Leningrad: Mashinostroenie.

2. Borisova, A.L., Borisov, Yu.S. (2008) Application of processes of self-propagated high-temperature synthesis in technology of thermal spraying of coatings. Poroshk. Metallurgiya, 1 / 2, 105-125.

3. Borisova, A.L., Borisov, Yu.S., Shvedova, L.K. et al. (1979) Interaction in $\mathrm{Cr}-\mathrm{SiC}$ system in conditions of conventional and plasma heating. Ibid., 10, 79-84.

4. Borisova, A.L., Borisov, Yu.S., Polyanin, B.A. et al. (1985) Interaction in $\mathrm{Ti}-\mathrm{SiC}$ composite powders and properties of sprayed coatings. Ibid., 10, 92-96.

5. Borisov, Yu.S., Borisova, A.L., Adeeva, L.I. et al. (1995) Composite plasma coatings $\mathrm{Ti}-\mathrm{Si}-\mathrm{C}$. Problemy Spets. Elektrometallurgii, 3, 62-70.

6. Borisov, Yu.S., Borisova, A.L., Shvedova, L.K. (1986) Transition metal-nonmetallic refractory compounds composite powders for thermal spraying. In: Proc. of ITSC on Advances in Thermal Spraying (Montreal, Canada, Sept. 8-12, 1986). Pergamon Press, 323-332.

7. Grigorenko, G.M., Borisova, A.L., Borisov, Yu.S. et al. (2002) Investigation of interphase interaction of ferrotitanium with silicon carbide in powder mixtures used for thermal spray coating. Advances in Electrometallurgy, 4, 30-33.

8. Grigorenko, G.M., Borisova, A.L., Borisov, Yu.S. et al. (2003) Investigation of interphase interaction of ferrotitanium with boron carbide in powder mixtures for deposition of thermal coatings. Ibid., 1, 26-29.

9. Murashov, A.P., Astakhov, E.A., Demianov, I.A. et al. (2003) Wear resistance of thermal coatings produced from composite powders «ferroalloys- $\mathrm{B}_{4} \mathrm{C}$, SiC. The Paton Welding J., 7, 43-44.

10. Lovshenko, G.F., Lovshenko, F.G., Khina, B.B. (2008) Nanostructural mechanically alloyed materials on the base of metals. Mogilyov: BRU.

11. Firstov, S.A., Gorban, V.F., Pechkovsky, E.P. (2009) New method of treatment and analysis of results of automatic indentation of materials. Kiev: Logos.

12. (1986) Properties, production and application of refractory compounds: Refer. Book. Ed. by T.Ya. Kosolapova. Moscow: Metallurgiya.

13. Leyland, A., Matthews, A. (2000) On the significance of the $H / E$ ratio in wear control: A nanocomposite coating approach to optimized tribological behavior. Wear, 246, 1-11.

14. Gorlenko, A.O., Shupikov, I.L., Topolyansky, P.A. et al. (2012) Modification of operating surfaces of parts by deposition of strengthening nanocoating. Metalloobrabotka, 2, 31-36.

Received 16.12.2013 